\title{
UMA HISTÓRIA ÍNTIMA DE CRIAÇÃO
}

\section{AN INTIMATE STORY OF CREATION}

Tânia Farias ${ }^{1}$

\section{Resumo}

O artigo sobre a desmontagem Evocando os mortos - Poéticas da experiência refaz o caminho da atriz na criação de personagens emblemáticos da dramaturgia contemporânea. Constitui um olhar sobre as discussões de Gênero, abordando a violência contra a mulher em suas variantes, questões que passaram a ocupar centralmente o trabalho de criação do grupo Ói Nóis Aqui Traveiz. O processo de desmontagem propõe um mergulho num fazer teatral onde o trabalho autoral condensa um ato real com um ato simbólico, provocando experiências que dissolvam os limites entre arte e vida e ao mesmo tempo potencializem a reflexão e o autoconhecimento. Desvelando os processos de criação de diferentes personagens, a atriz deixa ver quanto as suas vivências pessoais e do coletivo Ói Nóis Aqui Traveiz atravessam os mecanismos de criação.

Palavras-chave: Desmontagem, Processo criativo, Personagem, Teatro Ritual, Cena Contemporânea

\section{Resumen}

El artículo sobre el desmontaje Evocando os mortos - Poéticas da experiência rehace el camino del actor en la creación de personajes emblemáticos de la dramaturgia contemporánea. Se constituye una visión sobre lãs discusiones de género, tratando de las diversas formas de violencia contra las mujeres, cuestiones que ocupanun lugar central em el trabajo de Ói Nóis Aqui Traveiz. El proceso de desmontaje propone una inmersión em el trabajo teatral donde el actor-creador condensa um acto real y um acto simbólico, provocando experiencias que disuelven los límites entre arte y vida y al mismo tiempo posibilitan la reflexión y el auto-conocimiento. Revelando los procesos de creación de diferentes personajes, la actriz muestra lo cuanto sus vivencias personales y las del colectivo Ói Nóis Aqui Traveiz cruzan los mecanismos de creación.

Palabras clave: desmontaje, proceso creativo, personaje, teatro ritual, escena contemporânea

\begin{abstract}
The article about the deconstruction-performance Evocando os mortos - Poéticas da experiência rewrites the way of the actor during the creation of emblematic characters of contemporary dramaturgy. It settles a view over gender discussions, treating about different forms of violence against women, questions that have taken a central place in the creative work of Ói Nóis Aqui Traveiz. The process of deconstruction is a dive into theater-work where the authorial actor condenses a real act and a symbolic act, raising experiences that dissolve the limits between art and life and at the same time enables reflection and self-consciousness. By revealing the process of creation of different characters, the actress shows how much her personal experience sand the one sof the collective Ói Nóis Aqui Traveiz cross the mechanism of creation.

Keywords: deconstruction-performance, creativeprocess, character, ritual theatre, contemporaryscene
\end{abstract} ${ }^{1}$ Atuadora da Tribo de Atuadores Ói Nóis Aqui Traveiz. Coordenadora da Escola de Teatro Popular da Terreira da
Tribo. Criadora do Selo Editorial Ói Nóis Na Memória. 
O teatro é antes de tudo ritual e mágico, isto é, ligado a forças, baseado em uma religião, crenças efetivas, e cuja eficácia se traduz em gestos e está ligada diretamente aos ritos do teatro que são o próprio exercício e expressão de uma necessidade mágica espiritual. (ARTAUD, 1995, p. 75)

Um processo de criação carrega em si uma carga pedagógica muito forte. Estes momentos de descoberta do que realmente se trata o trabalho que estamos dissecando nos revelam muitas coisas. A aprendizagem pode carregar um pouco de história, política, mitologia e espiritualidade. Conhecimento sobre civilizações antigas que carregavam de outra forma o peso de sua existência.

Através dos meus quase 20 anos de Ói Nóis Aqui Traveiz, grupo gaúcho que surgiu no final da década de 70, e que este ano completou 36 anos de trajetória, participo de um projeto enraizado na cidade através das suas criações e do importante projeto pedagógico realizado pelos bairros de cidade de Porto Alegre com Oficinas populares de teatro, que visam a criação de grupos culturais nestas comunidades e em sua sede a Terreira da Tribo. Minha formação tem se dado através destes intensos trabalhos de pesquisa e laboratório junto ao grupo.

No momento em que a maternidade, ou melhor a ausência dela, começou a pesar no meu espírito, como um chamamento ancestral a que eu tinha recusado até então, começa a nascer em mim o desejo de organizar a experiência que eu vinha criando junto ao Ói Nóis para compartilhar com parceiros fazedores e aprendizes de teatro. A ideia de uma demonstração técnica de trabalho não dava conta do que gostaria de fazer. Gostaria de dividir meus segredos, já não podia guardá-los só para mim, os meus mais secretos estímulos de criação e minha fragilidade. A crença de que qualquer pessoa que tenha desejo de aprender algo, com acesso aos meios de aprendizagem, pode com certeza desenvolver-se, me fez acreditar que concretizar este desejo era dar meu testemunho de que isso ocorreu comigo. No meu caso pela inesgotável generosidade da Tribo de Atuadores.

Em 2010 realizamos o seminário Teatro, Performance e Política, no qual trouxemos para nossa casa Ileana Diéguez Caballero ${ }^{2}$ e Miguel Rubio Zapatta ${ }^{3}$. Neste momento entro em contato com a ideia de desmontagem como "Poéticas da Experiência" e não de demonstração técnica. Pela primeira vez entrava em contato com o conceito daquilo que eu buscava. Miguel Rubio, nesta ocasião, já havia me provocado: "por que você não faz uma desmontagem hoje pra nós?”

Esse encontro foi fundamental para dar direção à minha busca. Comecei a escrever sobre o meu processo, e o que mais me instigava era fazer um inventário dos meus trabalhos anteriores. Por

${ }^{2}$ Pesquisadora cênica de origem cubana radicada no México. Professora do Departamento de Humanidades da Universidade Autônoma Metropolitana, Unidad Cuajimalpa.

${ }^{3}$ Diretor e membro fundador do Grupo Cultural Yuyachkani, coletivo fundado em 1971 que, da mesma forma que grupos latino-americanos similares, percorre caminhos de pesquisa sustentados na investigação do comportamento cênico do ator desde a perspectiva de uma cultura de grupo. 
isso, voltei a cada uma das personagens mais instigantes que criei no Ói Nóis.Como sempre, reencontrei canções, línguas, culturas e a mim mesma na história de outras mulheres. Muito rico e triste. Toda criação carrega um pouco de tristeza. Não sei, ou não quero explicar isso. Mas é assim. Evidente que não só tristezas, também descobertas, satisfação profunda ao perceber-se encontrando ou reencontrando o outro. A criação e sua proximidade com a morte. Existem coisas que são de outro campo. Não sei explicar. E não me preocupo por não conseguir explicá-las. Meu trabalho passou a chamar-se Evocando os mortos: Poéticas da experiência.

\section{Um: Ofélia/Rebelião}

Trabalhamos com o texto Hamlet Machine, de Heiner Müller ${ }^{4}$, no qual os personagens da peça de Shakespeare são retirados do seu contexto para servir ao autor na sua crítica à experiência do Estado socialista na Alemanha e seu questionamento quanto ao papel do intelectual e artista neste quadro.

Cieslak ${ }^{5}$ nos disse:

A partitura é como um copo de vidro no qual está uma vela acesa. O vidro é sólido, está ali; você pode confiar. Contém e guia a chama da vela. Porém, não é a chama. A chama é meu processo interior de cada noite. A chama é o que ilumina a partitura. Ilumina o que o espectador vê através da partitura. A chama está viva. Assim como a chama da vela atrás do vidro se move, flutua, se expande, se encolhe; quase apaga e volta a brilhar intensamente, reage a cada sopro de vento, também minha vida interior varia a cada noite, de momento em momento... Começo, cada noite, sem antecipar nada. Esta é a coisa mais difícil de aprender. Não me preparo ensaiando. Não digo: "na vez passada, esta cena era extraordinária, tratarei de voltar a fazê-la". Quero somente estar pronto para o que vier a acontecer. E me sinto pronto para alçar o voo que poderá acontecer se me sinto seguro na partitura, sei que também quando não sinto quase nada o vidro não se romperá porque a estrutura objetiva, trabalhada por meses, me ajudará. Quando chega a ocasião em que posso arder, brilhar, viver, revelar - então estou pronto porque não o antecipei. A partitura é a mesma, porém cada coisa é distinta, porque eu sou distinto. (CIESLAK, 1994, p. 22).

No caso de Ofélia o copo foi construído a partir das ações físicas. Criei na sala de trabalho uma partitura de ações não cotidianas, que deram origem à personagem. A chama eu tratava de buscar na minha própria experiência de violação e violência. Não como memória afetiva no sentido stanislaviskiano, mas na presença desta memória de dor contida nos ossos, na musculatura, no corpo. Fui vítima de um estupro, eles eram três jovens e uma criança (menino de 10 anos no

\footnotetext{
${ }^{4}$ Heiner Müller (1929-1995) foi dramaturgo e escritor alemão. Sua carreira literária teve início quando o socialismo estava sendo construído na República Democrática Alemã, o lado leste da já dividida Alemanha. Müller é considerado um discípulo e seguidor da obra de Bertolt Brecht. É lembrado como um dos principais autores que refletiram sobre a história recente do país.

${ }^{5}$ Ryszard Cieslak, ator que foi um dos maiores colaboradores de Grotowski.
} 
máximo), eram de uma região onde a pobreza é muito grande, gerando um quadro de violência acentuada.

Engraçado pensar nas minhas origens. Sou descendente de portugueses e espanhóis. Na América foram eles os responsáveis pelo grande genocídio dos povos originários e não foram poucos os estupros neste contexto. É como uma vingança histórica.

$\mathrm{Na}$ contração total da musculatura buscar a afetividade contida nos ossos. $\operatorname{Artaud}^{6}$ afirma: "Para existir basta abandonar-se ao ser. Mas para viver é preciso ser alguém e para ser alguém é preciso ter um OSSO, é preciso não ter medo de mostrar o osso e arriscar-se a perder a carne." (ARTAUD, 1983, p.153)

Acredito que Ofélia é uma força e não uma personagem. A morte de meu pai a menos de um ano me aproximava dela no contexto shakespeariano, e o estupro me fazia ler de forma muito pessoal a revolta da Ofélia de Heiner Müller em seu gesto de romper com o mundo doméstico, reservado as mulheres, ao jogar pela janela todos os móveis e utensílios domésticos numa clara alusão a Ulrike Meinhof ${ }^{7}$.

Na Tribo não é raro um ator pensar em uma cena e eleger pra ela um aroma. A cena em que Ofélia destrói os instrumentos do que chama de cativeiro, cheirava a perfume de rosas. Uma experiência muito forte para mim foi a morte de uma antiga atuadora do grupo que se chamava Maria $\operatorname{Rosa}^{8}$, eu mesma nunca tive a oportunidade de trabalhar com ela. Já há muito tempo estava afastada do grupo e quando a conheci já estava bastante doente, tinha um tumor no útero. Percebia que ela era uma mulher muito forte e que tinha deixado um rastro importante no trabalho do Ói Nóis. No seu enterro as pessoas cantavam canções e músicas alegres e fortes para homenageá-la. A capela tinha um forte cheiro de perfume de rosas. Quando logo depois pensei num odor para a cena desta outra guerreira, a nossa Ofélia, quis fazer a minha homenagem silenciosa.

$\mathrm{Na}$ cadeira de rodas, as pernas sempre num ponto de vibração fazendo com que todo o corpo tremesse. A voz (ação vocal) seguia a sugestão e saía trêmula e frágil, ainda que em volume alto. Já na camisa de força, Ofélia fala em nome de Electra, a vingadora. A loucura em Ofélia é uma resposta do corpo, algo se rompe, algo age de forma autônoma, sem passar pela razão. Ofélia enlouquece com o assassinato do pai pelo amado, conflito masculino resolvido através da espada.

\footnotetext{
${ }^{6}$ Antonin Artaud (1896-1948) foi um poeta, ator, escritor, dramaturgo, roteirista e diretor de teatro francês de aspirações anarquistas.Sua obra $O$ Teatro e seu Duplo é um dos principais escritos sobre a arte do teatro no século XX. ${ }^{7}$ Ulrike Meinhof (1934-1976) foi jornalista, escritora, ativista e guerrilheira alemã, mais conhecida como integrante da organização de extrema-esquerda Fração do Exército Vermelho (RAF), também conhecido como Grupo BaaderMeinhof, atuante na Alemanha Ocidental por três décadas.

${ }^{8}$ Atuadora do Ói Nóis Aqui Traveiz de 1985 a 1989. Criou e atuou nos espetáculos Teon-Morte em Tupy Guarani, Fim de Partida e Ostal - Rito Teatral.
} 
Sempre busco, a cada trabalho, criar um caderno com as referências que surgem ao longo do caminho para criação do espetáculo e personagem. Encontramos um livro muito bacana com as fotos de Jan Saudek ${ }^{9}$, que foi fundamental para descobrir o tom das cenas com o coro de mulheres suicidadas. Digo Suicidadas como Van Gogh, segundo Artaud, o suicidado da sociedade. Acabou aparecendo na personagem e em seguida na cena um tom que vou chamar de anti-pornografia. Ofélia e este coro de mulheres suicidadas traziam o sexo em evidência e sem qualquer vestígio de pelos. Detalhe frequente em revistas masculinas e que aqui adquiria um sentido de anti-pornografia, pois as imagens femininas eram bem grotescas.

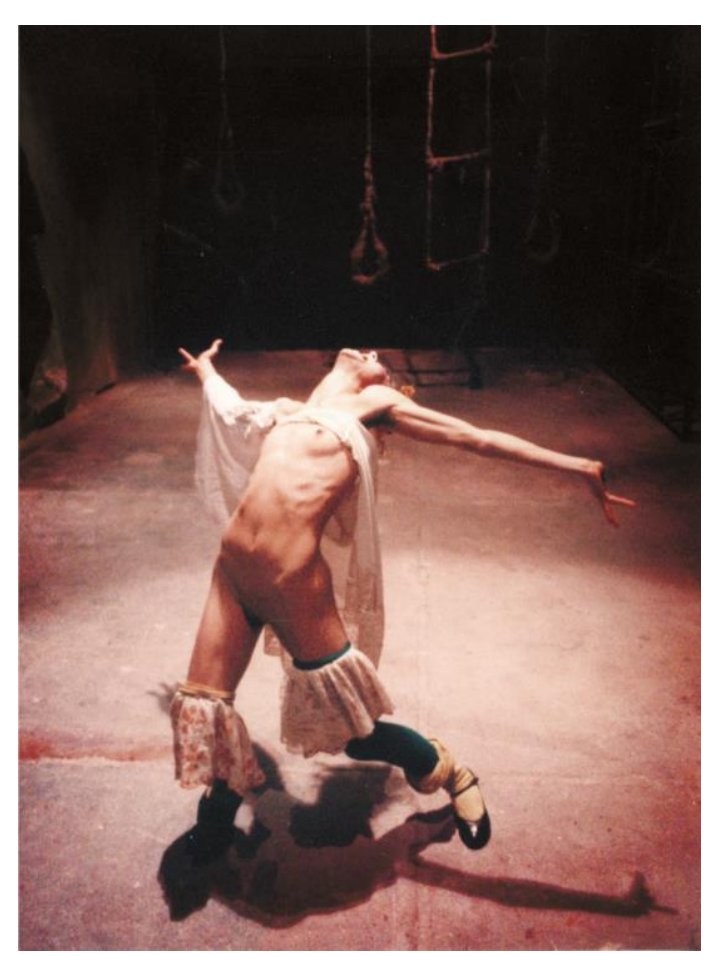

Imagem 1 - Ofélia - Hamlet Máquina - 1999. Foto Cláudio Etges

Não me apropriei do trabalho de construção de personagem até que descobri o ponto de vibração de minhas pernas, fazendo com que tremessem sem que eu fizesse qualquer esforço. Metaforicamente, o aparente descontrole da loucura para mim estava neste movimento, nesta parte do corpo. Enquanto realizava as ações, as pernas tremiam involuntariamente. Refletir sobre a

${ }^{9}$ É considerado um dos fotógrafos mais excêntricos da atualidade. Também é desenhista e pintor: a estética de sua fotografia é tão similar aos seus outros trabalhos. Embora pouco conhecido no Brasil, Jan Saudek é o fotógrafo mais famoso da República Tcheca. Seu estilo inclui pintar à mão suas fotografias, deixando-as com tons sépia e aparência do século XIX. Seus modelos traçam um comportamento teatral diante da câmera, tomando posições suaves e intensas, como se dialogassem uns com os outros ou com o cenário pela linguagem corporal. 
loucura foi necessário para compreender o que estava defendendo em cena. Artaud nos diz: “E o que é um autêntico louco? É um homem que preferiu ficar louco, no sentido socialmente aceito, em vez de trair uma determinada ideia superior de honra humana. Pois o louco é o homem que a sociedade não quer ouvir e que é impedido de enunciar certas verdades intoleráveis." (ARTAUD, 1983, p.4). Este pensamento de Artaud introduz outra personagem tida como louca por suas verdades intoleráveis: Kassandra.

\section{Dois: Kassandra/Minúcia e reconciliação com o ventre}

Com Kassandra tinha um desafio inicial que era criar uma personagem com maior complexidade e contradições. No mito conhecemos Kassandra como aquela que diz a verdade, mas que não tem o poder da persuasão, não consegue fazer com que acreditem no que diz. Isso acontece porque ela não quis entregar-se ao Deus Apolo do qual é sacerdotisa. Ele cospe-lhe na boca.

Em algum momento dei-me conta que a única coisa que possuímos de verdade é nosso corpo, um universo particular, que só a nós pertence. Quando não nos permitem escolhas sobre ele, estão quebrando nossa fortaleza, nosso bem mais precioso, nossa liberdade de escolha no universo mais íntimo. Neste caso, a liberdade de escolha de Kassandra custou-lhe toda a possibilidade de crédito.

Nossa Kassandra partia de relações mais concretas no campo social e político. Era uma mulher que participava das discussões políticas e com isso adquiriu a capacidade de pensar livremente e ter as próprias opiniões. Neste momento, a Tribo estava passando por um período de luta na cidade, um embate político pela preservação no nosso Centro de Experimentação e Pesquisa Cênica, um espaço aberto que, além de ser a sede do Ói Nóis, ventre gerador dos processos de pesquisa do grupo é também onde o Ói Nóis desenvolve a sua Escola de Teatro Popular, com Oficinas abertas e gratuitas.

Era um período (1984) no qual nós ainda sofríamos com a censura, com falta de espaços de liberdade. A Terreira foi um grande atelier artístico que reuniu artistas visuais, músicos, atores e ativistas. Várias bandas de rock surgiram ali. As pessoas podiam ficar naquele lugar bebendo uma cerveja, trocando ideias. Transformou-se numa espécie de símbolo de liberdade. Num momento em que isso era tão difícil, no qual nos sentíamos permanentemente sob vigilância, ali constituiu-se um reduto de liberdade.

Eu participava das reuniões públicas pela preservação da Sede, a Terreira da Tribo. Não foram poucas as vezes que me deparei com um contexto muito machista, hostil e dissimulado, pelo 
fato de eu ser mulher e jovem. Lembro-me de reuniões em que isso incomodava muito os homens que naquele momento representavam o poder constituído na cidade. Não era conveniente que o grupo fosse defendido, menos ainda por uma mulher e tanto pior, uma jovem mulher. A convicção com que eu o defendia tornava tudo ainda mais “intolerável”. Eu cobrava o direito da população de manter a memória deste lugar tão marcante na história sócio cultural da cidade.

Kassandra entra em conflito com o Estado, com o próprio pai, o Rei Príamo. Ela queria impedir a Guerra. Não era conivente com todas as mentiras criadas para justificar um conflito que tinha como única razão a pilhagem, o imperialismo. Numa sociedade que não valoriza a vida, ela era uma voz contra a iniquidade. Alimentávamo-nos de tudo o que estávamos vivendo para a construção da personagem e da peça. Uma das minhas primeiras ações consistia em bater contra o ventre e logo depois segurar o punho da mão direita em frente ao corpo. Com este gesto minhas primeiras palavras como Kassandra:

Eu fui testemunha... das idas e vindas entre o palácio e os sacerdotes do templo, das reuniões diurnas e noturnas do conselho. (Golpeia o ventre, com a palma da outra mão interrompe a trajetória do punho que busca impulso para um novo golpe numa sequência que se repete.) Até que se fabricou uma notícia de impacto, bem martelada, polida como uma lança. (Golpeia o ar com o punho fechado de cima para baixo, interrompendo o movimento antes que se conclua, retendo energia e buscando precisão. O joelho da perna direita repete o mesmo movimento do pulso ao mesmo tempo. Salta para o alto e vai ao chão sentando-se sobre a perna direita enquanto a esquerda está alongada. Os braços livres comentam o texto com o público.) Páris, o herói troiano, raptara do gregos, Helena. A mais bela mulher da Grécia. O povo? (Se ergue enquanto o quadril solto tremula lateralmente e as mãos acompanham este movimento.) $\mathrm{O}$ povo percorria as ruas festejando. De tanto se repetir uma coisa acabamos crendo nela. (WOLF, 1990, p.72)

O tom era irônico e as ações faziam um comentário independente. Esta ação da personagem era interrompida no espetáculo por uma engrenagem de violência à mulher. Isso se passava num outro plano. Enquanto isso, numa ação paralela, atriz/personagem Kassandra cuidadosamente, por entre as pernas do público, tirava de baixo da saia pequenos (do tamanho da palma da mão) homenzinhos azuis. A este espaço denominamos campo de batalha e o seu piso era coberto por muito mármore triturado. Ao caminhar afundávamos os pés nas pedrinhas. Sobre este solo branco e estéril Kassandra depositava seus homenzinhos, num movimento ao mesmo tempo mecânico e preciso, mas também desesperado. Trabalhava na construção de uma base firme e com o corpo em constante oposição.

Neste período, o Partido que estava no poder em nossa cidade ganhava cada vez mais espaço no país. Eles tinham sempre a razão e ninguém queria se indispor com quem ocupava tais cargos de governo. O silêncio que vivenciei nestes tempos por parte dos demais artistas me fez 
optar por uma frase para Kassandra que em verdade é de Medeia Vozes de Christa Wolf": "Haverá um mundo, um tempo, um lugar pra mim? Ninguém a quem possa perguntar, esta é a resposta." (WOLF, 1996, p. 204)

Devo dizer que mesmo quando nós, no grupo, partimos de um texto, este serve mais como ponto de partida do que como roteiro da encenação, o trabalho com recorte e colagem de texto é um recurso muito utilizado. Esta prática é reforçada uma vez que cada ator em nosso processo de criação coletiva, além das improvisações, elabora e dirige cenas em um processo que chamamos internamente de Ritual da Personagem. Um momento em que cada atuador envolvido no processo elabora uma cena propondo textos, figurinos, cenografia, propostas de iluminação. Esse tipo de trabalho nunca toma como referência única o autor e constrói uma dramaturgia própria mesmo quando mantém como base um texto pré-existente. Em Kassandra partimos da novela de Christa Wolf que, uma vez que não é um texto dramático, já nos dá muito mais abertura para conceber cada cena. E no processo fomos descobrindo outros textos.

Lembro-me que meu Ritual da Personagem trouxe duplos de Kasssandra e um fragmento de texto de Heiner Müller de uma obra chamada Germânia 3: Morte em Berlim. Neste texto há um diálogo entre Hitler e Stalin, cada um destes homens coleciona uma série de assassinatos, que não faz nenhuma diferença entre um se colocar como a esquerda e outro a direita. Cometeram assassinatos em massa. Outra referência que trouxe foram poemas de Pablo Neruda. Fiquei muito envolvida por seu livro Canto Geral. Para a cena de ternura entre Kassandra e Enéias trouxe a discussão dos dois revolucionários de Os Justos de Albert Camus.

Como preparação para este trabalho buscamos uma professora de dança do ventre. $\mathrm{O}$ objetivo era trabalhar esta parte do corpo, ativá-la, percebê-la de forma mais aguda. Quando fomos criar uma cena em que Kassandra é iniciada nos ritos da Deusa Mãe improvisamos muito e chegamos a elaborar várias versões da cena utilizando movimentos da dança. E o momento mais importante foi quando percebemos que não deveríamos utilizá-los desta forma, e sim como bagagem pessoal, cada atuadora estava em cena com este ventre desperto e isso era o que tínhamos de mais importante para elaborar a cena e não os movimentos codificados.

Kassandra foi um intenso processo de aprendizagem e descobertas e, por isso, também longo e doloroso. Uma das últimas cenas de Kassandra era justamente o estupro que sofre por Ajax.

${ }^{10}$ Christa Wolf (1929-2011) foi uma das mais importantes escritoras contemporâneas de língua alemã. Crítica literária,
novelista e ensaísta, controversa e ainda assim uma das mais celebradas autoras vindas do leste europeu. Viveu na RDA
(República Democrática Alemã). Seus temas foram, desde o início de sua carreira ligados ao ambientalismo,
possibilidades de guerra nuclear, excessos da ciência, passado nazista da Alemanha, feminismo e o papel dos marginais. 
Ajax, não esquecer este nome. Kassandra tem uma frase que me acompanha desde então, ela não aparecia no espetáculo de forma direta mas estava certamente em alguma parte de meu corpo de mulher e atuadora: "Quero me manter testemunha, ainda que não haja mais ninguém para solicitar meu testemunho." (WOLF, 1990, p.32)

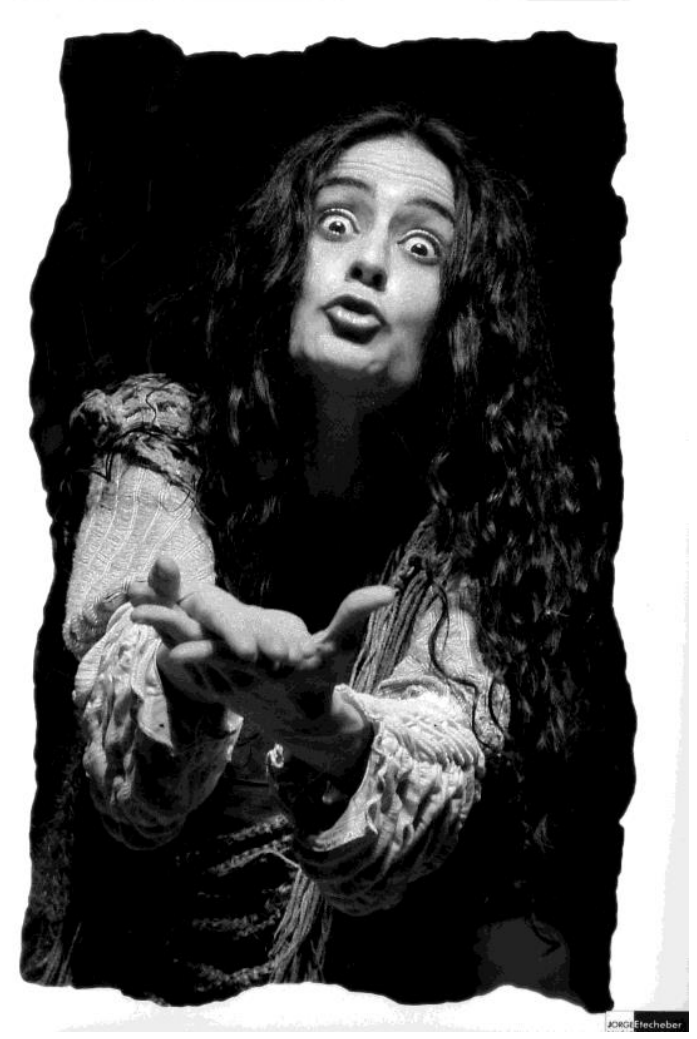

Imagem 2: Kassandra - Aos que virão depois de nós - Kassandra in Process - 2002. Foto Jorge Etecheber

Nosso próximo trabalho partiu de um texto teatral de Heiner Müller, A Missão Lembrança de uma Revolução. Nesta obra, Müller vai usar a Revolução Francesa para contar a história de um grupo de revolucionários franceses que vai a Jamaica fomentar uma revolta de escravos. Um burguês, um camponês e um negro. Partem para a Jamaica com esta missão.

\section{Três: Dar musculatura as palavras}

Durante toda a peça invertemos a questão racial pela problemática de gênero. Todos os negros que aparecem na obra de Müller foram trocados por mulheres. Uma afirmação de John 
Lennon colaborava com isso: “A mulher é o negro do mundo, ela é a escrava dos escravos. Se ela é livre, você diz que ela não te ama. Se ela pensa, você diz que ela quer ser um homem""11

A situação do povo haitiano hoje, a intervenção brasileira que segue o modelo imperialista norte-americano, constrangia a todos. Um país de minorias como o Brasil acreditando ter a solução para um conflito interno de outro país pobre e cheio de problemas sociais. O vodun ${ }^{12}$ serviu de referência para esta pesquisa e nossos corpos (das mulheres do coro de escravos e de Sasportas, personagem que eu assumi) tinham um quadril/o centro orgânico em constante movimento, um tambor estava pulsando ali. Os vevês (inscrições feitas no chão que identificam as Loas [deidades]dos cultos de vodun no Haiti) serviam de roteiro para o desenho dos corpos pelo espaço.

Durante o processo tivemos aulas de tambores do ritual africano. Cada uma das mulheres envolvidas no processo tocou um dos três tambores que compõem o ritual. Isso foi muito revelador. Os timbres destes tambores são absolutamente diferentes e ao tocá-los é como se um deles te escolhesse. Um serve de base é o mais grave (Run) e suas batidas geralmente funcionam como um pulso condutor. Run Pi é como chama-se o tambor de timbre equilibrado. Mantém a harmonia do ritmo. O Lê é o tambor mais agudo, suas batidas têm grande variação e agilidade. Este último parece ter me escolhido e suas nuances deram ritmo ao tambor que imaginei levar dentro do ventre.

Na busca de distanciar-me um pouco do trabalho com as ações físicas, parti do ritmo das canções do vodun e de algumas características físicas que surgiram ao longo do trabalho com improvisações. Surge o negro e sua intensa máscara com as cores negra, branca, amarela e vermelha. Minha necessidade de dar a ele características próprias que não estivessem ligadas apenas ao meu biótipo levou a utilização de uma lente em um dos olhos, na verdade a ideia surge da observação de um cachorro que tinha um olho de cada cor, sendo um deles branco, todos nos perguntávamos se ele enxergava daquele olho. Isto me pareceu curioso e me trouxe até este experimento aprovado pelos meus companheiros de grupo.

Busquei para o momento em que Sasportas opta por permanecer com os escravos jamaicanos, no fomento de uma revolta, corporificar as ideias do texto. Eu queria dar músculos as palavras: "Os meus cúmplices serão os escravos de todas as raças, cujo número cresce... em cada instante em que tu passas na gamela dos senhores de escravos ou entre as coxas da tua puta branca"

\footnotetext{
${ }^{11}$ Woman Is the Nigger of the World, de John Lennon and Yoko Ono. Album Some Time in New York City, 1972.

${ }^{12} \mathrm{~A}$ palavra vodu vem do vocábulo africano Dahomey vodun, que significa espírito ancestral. O termo vodun aplica-se aos ramos de uma tradição religiosa teísta-animista baseada nos ancestrais, que tem as suas raízes primárias entre os povos Fon-Ewe da África Ocidental, no país hoje chamado Benin, anteriormente Reino do Daomé ou Dahomey, onde o vodu é hoje em dia a religião nacional de mais de 7 milhões de pessoas.
} 
(MÜLLER, 1987, p.55), enquanto eu fazia uma contração da coluna, jogando quadril, cabeça e ombros para frente e depois para traz, criando uma ponte imaginária entre os chacras básico e do coração. Estas palavras vinham acompanhadas de uma risada sarcástica que tinha como inspiração uma entidade do vodun, o Eleguá que tem seu correspondente no candomblé afro-brasileiro com o Exu. Enquanto isso, os braços se moviam flexionados e as mãos tocando as costelas, como asas curtas. Mantinha o quadril (koshi $)^{13}$ muito rebaixado, o que fazia com que meus joelhos estivessem sempre bastante flexionados e minha base mais ampliada. Trabalhei os elementos plásticos, imaginando pequenas explosões internas nesta região da bacia, enquanto os braços pesados pendiam do corpo com as axilas descoladas. "Eu serei montanha!” Enquanto eu falava este texto tinha os cotovelos flexionados e as mãos e antebraços para cima e iniciava um movimento frenético. “Eu, isto é a África! Eu, isto é a Ásia! As duas Américas sou eu!” Corta o movimento bruscamente.

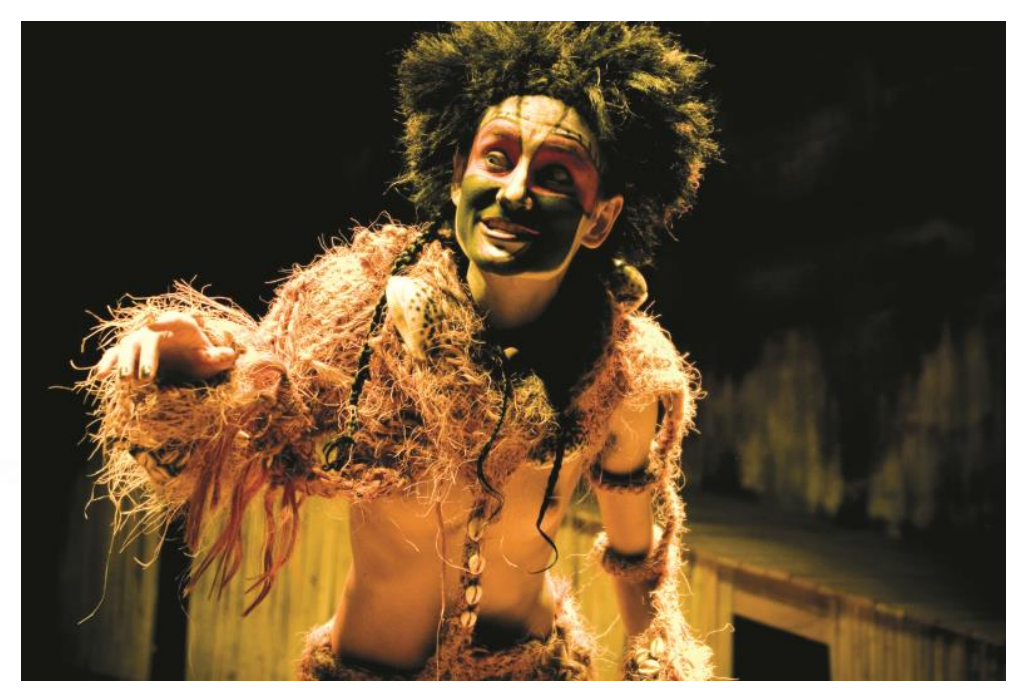

Imagem 3: Sasportas - A Missão - Lembrança de uma revolução - 2006. Foto Cisco Vasques

O corpo se evidencia num traje feito de sisal tingido, com seios e sexo caracterizando o coro de escravos como um todo. O negro/escravo/revolucionário nada tem a perder quando estes três enviados da França recebem a indicação para abandonarem a Missão. Com sua pele negra, como mais uma mulher, ao lado dos seus, segue no fomento da revolta.

\section{Quatro: Sob o signo da América Latina}

\footnotetext{
${ }^{13}$ Região do abdômen, trabalha-se na preparação do ator com a ativação deste ponto que, em japonês, também significa a presença do ator. (Burnier, 1994, p. 149)
} 
Neste último trabalho que vou comentar tive uma das experiências mais fortes e importantes da minha trajetória dentro do Ói Nóis Aqui Traveiz. Partimos do texto Viúdas do chileno Ariel Dorfman ${ }^{14}$. Ele cria um povoado imaginário onde todos os homens estão desaparecidos, restando apenas as mulheres. Elas têm o protagonismo quando se trata de garantir a memória dos desaparecidos e mortos nas Ditaduras Latino-americanas. São Madres de la Praça de Mayo, são Abuelas. São as viúvas brasileiras que lutaram por resgatar a memória de seus companheiros e cobrar do Estado o que lhes era de direito, participando ativamente na Luta pelos Direitos Humanos. Isto me serviu muito de inspiração no processo de construção de Viúvas.

Estávamos em processo quando o Ministério dos Direitos Humanos lançou um livro sobre as mulheres mortas, desaparecidas, que incluía depoimentos de brasileiras que sofreram tortura durante a Ditadura Brasileira. A leitura foi penosa, lembro-me de parar e pensar que não podia continuar a ler aqueles depoimentos. Minha caixinha de imagens, de referências (hábito que me acompanha a cada criação) estava preenchendo-se com terríveis pesadelos. No Brasil, o empenho de tal Ministério ao publicar este livro era levar o processo brasileiro a criar a nossa Comissão da Verdade.

Logo em seguida, nós (Ói Nóis) criamos o Festival de Teatro Popular - Jogos de Aprendizagem. Na sua primeira edição realizamos um antigo desejo: o de se encontrar com grupos irmãos latino-americanos. Grupos que como o Ói Nóis fazem parte de uma linhagem que é a do Teatro Independente Latino-americano. Grupos com uma longa existência e trabalhos fortemente ligados as suas comunidades. Convidamos o grupo peruano Yuyackani e tivemos um encontro maravilhoso aqui em Porto Alegre. Os espetáculos que se apresentaram aqui foram Adiós Ayacucho com Augusto Casa Franca e Rosa Cutillo com Ana Correa. Foi uma experiência importante este encontro, estávamos com dois atores do que podemos chamar, fazendo uma brincadeira com o grupo, de facção Andina do Yuyackani.

O trabalho de ambos nos dava muito subsídio para a criação de Viúvas, e tanto Ana como Augusto me presentearam canções em quechua ${ }^{15}$ : Augusto, uma canção que também é utilizada em um espetáculo do seu grupo e Ana, uma canção de cuna para uma niña. Gravamos estas canções e eu as assimilei para Sophia. Evidentemente que sem um compromisso de reproduzir tal qual Ana ou

\footnotetext{
${ }^{14}$ Nasceu na Argentina, em 1942, e naturalizou-se chileno. É professor de literatura e estudos latino-americanos na Duke University, na Carolina do Norte. Co-autor do best-seller Para ler o Pato Donald, publicou no Brasil, entre outros, Super-homem e seus amigos do peito, a autobiografia Uma vida em trânsito e a peça A morte e a donzela, montada em noventa países e filmada, em 1994, por Roman Polanski.

${ }^{15} \mathrm{O}$ quechua ou quichua é uma família de línguas originárias dos Andes Centrais. Teve a sua origem há milênios na região central e ocidental do Peru. Esta língua diversificou-se em várias e até ao século XV o chamado quechua clássico converteu-se na língua oficial do império inca. Atualmente é muito falada em países como Bolívia, Peru e Equador.
} 
Augusto as cantavam, mas procurei ser minuciosa com a pronúncia. Já a canção de cuna eu não tinha toda a letra, então tratei de inventar uma segunda parte. A primeira diz assim:"Yael sol esta se ocultando / Ya La luna está llegando / Vem vamos ya no sufra em tierras ajenas / Deja el llanto, la pena / Em estes lugares que no te pertenecen". E a outra: "Descansa tranquilamente / Com dulces sueños / Me vienem cuentos com arrullos / Duerme dulcemente hermanita/hijita". A sonoridade destas canções é muito própria e falaram ao meu espírito assim que as escutei pela primeira vez. Quando o público encontrava Sophia, ela estava cantando esta canção sentada em uma pedra. Cantava para seus quatro homens desaparecidos e mortos.

Após realizar os rituais de personagem começamos a buscar o espaço para realizar a ação cênica, e encontramos a Ilhas das Pedras Brancas, mais conhecida como Ilha do Presídio, onde estão as ruínas de um antigo presídio que serviu de cárcere para presos políticos durante a Ditadura Militar. O público era levado de barco até a Ilha, a performance começava ainda na embarcação sobre as águas do nosso Rio Guaíba.

Não pretendia trabalhar com ações não cotidianas e tão pouco construir uma personagem no sentido clássico. Eu queria que se pudesse ver a atriz por trás de Sophia. Eu não tenho 70 anos. Eu não tenho esta trajetória em meu corpo, ao menos não, no corpo material. Com isso, queria apenas que acreditassem em mim. Uma única característica eu agreguei a Sophia: ela mancava de uma perna. Como Rosa Luxemburgo que também foi morta por suas ideias. Morta pela intolerância. Pela manutenção das coisas como elas são.

Quando pensei que Sophia deveria aparecer num momento pleno, imaginei logo a Festa da Colheita da qual fala e tudo que pode significar celebrar os frutos que a terra nos dá: a celebração da vida. E é nesse contexto que Sophia conhece o seu amor. Quando criei o momento de encontro de Sophia e Miguel na Festa ela não mancava, no seu momento de plenitude seu corpo está inteiro, sem marcas. A perna que não podia mover-se normalmente não esteve sempre aí, era uma cicatriz, uma marca dos anos de espera: "Estou esperando meu pai, meu marido e meus filhos. Há muito temos esperado. Demasiado." (DORFMAN,1996, p. 92)

Outra referência forte para o processo de encontro com Sophia foi ter conhecido a viúva de Carlos Marighella ${ }^{16}$, Clara Charf. Ela se mantém como sua viúva e dedicou a vida à manutenção viva de sua memória que setores da sociedade se esforçaram em apagar. Sem sucesso no entanto,

\footnotetext{
${ }^{16}$ Carlos Marighella (1911-1969), poeta, deputado federal democraticamente eleito, militante baiano que lutou contra duas ditaduras: a do estado novo de Getúlio Vargas e a Ditadura Civil-militar instaurada no país com o golpe de 1964. Foi figura emblemática na luta por transformações sociais e ficou conhecido como o Inimigo $\mathrm{N}^{\circ} 1$ da Ditadura. Foi assassinado pelo regime ditatorial em 1969 na Alameda Casa Branca, em São Paulo.
} 
hoje no Brasil vemos várias ações que colocam Marighella como fruto de sua história e dono de uma trajetória singular.

Ainda no período de busca de materiais, encontrei o velho livro Se me deixam falar... um depoimento de Domitila Barrios Chungara ${ }^{17}$, mulher mineira boliviana que foi até um encontro internacional de representantes de várias nações para denunciar as condições dos trabalhadores das Minas em seu país.

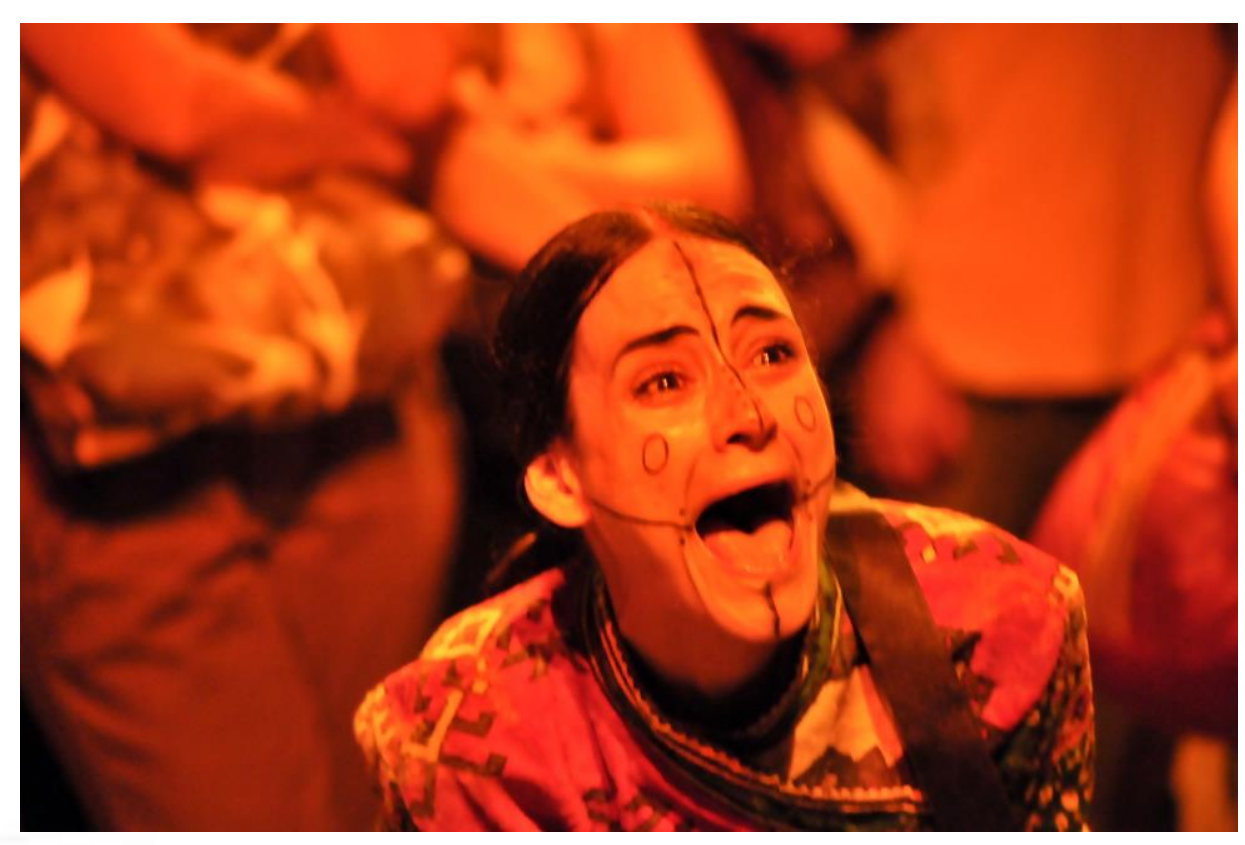

Imagem 4: Sofia - Viúvas - Performance sobre a ausência 2011. Foto Claudio Etges

Tive a oportunidade de realizar este trabalho em dois momentos diferentes. Do primeiro para o segundo fiz uma viagem a Lima, no Peru, para as celebrações de aniversário do grupo Yuyachkani, conto isso porque muita coisa mudou para mim depois de entrar em contato com as mulheres peruanas que encontrei no comércio de uma localidade bastante caótica no Peru. Em busca de trajes encontrei mulheres de origem indígena que traziam no corpo as marcas do tempo e no espírito uma alegria, a celebração por mais um dia, podia vê-la em seus olhos.

Repensar os procedimentos e inspirações que nortearam as minhas escolhas nestes diferentes processos criativos me fez perceber o quanto mudamos a cada novo trabalho. O quanto eles alimentam e estimulam a nossa ação no cotidiano. Pude perceber que através do teatro mudei a

\footnotetext{
${ }^{17}$ Domitila Barrios Chungara (1937-2012) ficou conhecida no mundo todo depois da publicação do livro Si me permiten hablar... Testimonio de Domitila - uma mujer de las minas de Bolivia. Mulher corajosa que foi pedra no sapato das ditaduras militares que governaram a Bolívia, entre 1964-1982. Em 1977 ao aderir a uma greve de h fome foi seguida por milhares, em todo o país, até conseguir o decreto de anistia para os exilados políticos e a promessa de eleições.
} 
minha visão de mundo, me associei a outras mulheres e construí minha única certeza: eu não estou sozinha. E que existem, ainda, muitas coisas por dizer e construir no caminho de uma real emancipação. E que esta não se dará, certamente, em oposição ao mundo masculino, senão junto com ele. No processo coletivo de criação sente-se a necessidade de ver o outro, ou ainda ver-se no outro. Por outro lado, a oportunidade de falar do coletivo através de uma vivência, que não deixa de ser pessoal e única de cada atuador, é para o grupo um novo caminho, onde tudo soma-se e nada é subtraído. $\mathrm{O}$ atuador não se dilui no todo e sim potencializa-se, empodera-se. $\mathrm{O}$ atuador é sujeito de sua criação no coletivo, ele é seu dono e ao mesmo tempo seu maior tesouro. A experiência de compartilhar fragmentos deste processo, depois de tanto tempo, tem possibilitado a constante reelaboração do ato criativo e de um exercício de cidadania. Agradeço pelo privilégio e oportunidade de fazer parte de um coletivo tão generoso, instigante e contestador.

Queria terminar citando uma carta de Rosa Luxemburgo ${ }^{18}$ :

No pátio onde passeio chegam frequentemente carroças do exército, abarrotadas de sacos, de túnicas velhas e camisas de soldados, muitas vezes manchadas de sangue... São descarregadas e distribuídas pelas celas, consertadas, novamente postas em carroças para serem entregues ao exército. Outro dia, chegou uma dessas carroças, puxadas não por cavalos, mas por búfalos. Era a primeira vez que via esses animais de perto. São mais fortes e maiores que nossos bois, têm uma cabeça chata, chifres recurvados e baixos, o que faz com que sua cabeça, inteiramente negra, de grandes olhos meigos, se pareça com a dos nossos carneiros. Originários da Romênia, são um troféu de guerra... Os soldados que conduziam a carroça diziam ser muito difícil capturar esses animais selvagens e ainda mais difícil utilizá-los para carregar fardos, pois estavam acostumados à liberdade. Foram terrivelmente maltratados até compreenderem que perderam a guerra e que também para eles vale a expressão "vae victis" (ai dos vencidos)... Só em Breslau deve haver uma centena desses animais. Eles que estavam habituados as ricas pastagens da Romênia recebem uma ração parca, miserável. Trabalham sem descanso puxando todo tipo de carga e, assim, não demoram a morrer. Há alguns dias, portanto, entrou no pátio uma dessas carroças cheias de sacos. A carga era tão alta que os búfalos não conseguiam transpor a soleira do portão. O soldado que os acompanhava, um tipo brutal, pôs-se a bater-lhes de tal maneira com o grosso cabo do seu chicote que a vigia da prisão, indignada, perguntou-lhe se não tinha pena dos animais. "Ninguém tem pena de nós, homens", respondeu com um sorriso mau e pôs-se a bater ainda com mais força... Os animais deram um puxão e conseguiram transpor o obstáculo, mas um deles sangrava... Apesar da proverbial espessura e resistência da pele do búfalo, ela foi dilacerada. Durante o descarregamento, os animais permaneciam imóveis, esgotados, e um deles, o que sangrava, olhava em frente com uma expressão no rosto negro de criança em prantos. Era exatamente a expressão de uma criança que foi severamente punida e que não sabe por qual motivo nem por que, que não sabe como escapar ao sofrimento e a essa força brutal... Eu estava diante dele, o animal me olhava, as lágrimas saltaram-me dos olhos, eram as suas lágrimas.

Oh! Meu pobre búfalo, meu pobre irmão querido, aqui estamos os dois impotentes e mudos, unidos na dor, na impotência e na saudade.

\footnotetext{
${ }^{18}$ Rosa Luxemburgo, judia, polonesa, apaixonada militante, dirigente política e intelectual. Foi uma combatente de primeira hora na luta contra o capitalismo. Fundadora do Partido Comunista Alemão. Brutalmente assassinada juntamente com Karl Libknecht em janeiro de 1919. Esta carta de Rosa Luxemburgo a Sonia Liebknecht foi escrita durante o período que esteve presa, em 24 de dezembro de 1917.
} 
Quanto ao soldado, metera as mãos nos bolsos e passeando a grandes passos pelo pátio, ria e assobiava baixinho uma canção da moda. Diante de mim a guerra desfilava em todo o seu esplendor.

Sua Rosa

Querida, fique calma e alegre apesar de tudo. Assim é a vida. É preciso tomá-la corajosamente, sem medo, sorrindo - apesar de tudo. Feliz Natal! (LUXEMBURGO, 2000, p. 77-78)

\section{REFERÊNCIAS}

ARTAUD, Antonin. Linguagem e vida. Antonin Artaud. São Paulo: Editora Perspectiva, 1995. ARTAUD, Antonin. Van Gogh, o suicidado da sociedade. Porto Alegre, Publicação independente Ói Nóis Aqui Traveiz, 1983.

ARTAUD, Antonin. Para acabar com o julgamento de deus. In: Escritos de Antonin Artaud. Tradução e organização de Cláudio Willer.Porto Alegre: LP\&M, 1983.

BURNIER, Luís Otávio. A arte de ator. Da técnica à representação. Campinas: Editora da Unicamp, 1994.

CIESLAK, Ryszard. Máscara. Cuaderno Iberoamericano de reflexión sobre escenología, Ano IV, n ${ }^{\circ}$ 16. México: Escenología, 1994.

DORFMAN, Ariel. Viudas. Buenos Aires: Ediciones de la flor, 1996.

LUXEMBURGO, Rosa. Rosa Luxemburgo ou o preço da Liberdade. São Paulo: Editora Expressão Popular, 2000.

MÜLLER, Heiner. A Missão. In: Quatro textos para teatro. São Paulo: Editoria Hucitec, 1987.

WOLF, Christa. Cassandra. São Paulo: Estação Liberdade, 1990.

WOLF, Christa. Medeia Vozes. Lisboa: Edições Cotovia Lda.,1996. 